\title{
Phytotoxicity of Chromium on Germination, Growth and Biochemical Attributes of Hibiscus esculentus L.
}

\author{
Hira Amin ${ }^{1 *}$, Basir Ahmed Arain ${ }^{1}$, Farah Amin ${ }^{2}$, Muhammad Ali Surhio ${ }^{2}$ \\ ${ }^{1}$ Institute of Plant Sciences, University of Sindh, Jamshoro, Pakistan; ${ }^{2}$ National Center of Excellence in Analytical Chemistry, Uni- \\ versity of Sindh, Jamshoro, Pakistan. \\ Email: "hira.amin00@gmail.com
}

Received October $8^{\text {th }}, 2013$; revised November $7^{\text {th }}, 2013$; accepted November $18^{\text {th }}, 2013$

Copyright (C) 2013 Hira Amin et al. This is an open access article distributed under the Creative Commons Attribution License, which permits unrestricted use, distribution, and reproduction in any medium, provided the original work is properly cited.

\begin{abstract}
Chromium is found in all phases of the environment, including air, water and soil. The contamination of environment by chromium has become a major area of concern. Chromium effluent is highly toxic to plant and is harmful to their growth and development. In present study, a pot experiment was carried out to assess the phytotoxicity of chromium in Hibiscus esculentus at different concentration $\left(0.5,2.5,5,10,25,50\right.$ and $\left.100 \mathrm{mg} \cdot \mathrm{kg}^{-1}\right)$ of chromium metal. The phytotoxic effect of chromium was observed on seed germination, seedling growth, seedling vigor index, chlorophyll content and tolerance indices of Hibiscus esculentus. All results when compared with control show that chromium metal adversely affects the growth of Hibiscus esculentus by reducing seed germination and decreasing seedling growth. The toxic effects of chromium metal to seed germination and young seedling are arranged in order of inhibition as: $0.5>2.5$ $>5>10>25>50>100 \mathrm{mg} \cdot \mathrm{kg}^{-1}$ respectively. The toxicity of chromium metal to young seedling and their effects on chlorophyll content were increased with higher concentration of chromium in the soil system. The major inhibitory effect of chromium in Hibiscus esculentus seedling was determined as stress tolerance index (\%). The present study represents that the seed and seedling of Hibiscus esculentus has potential to counteract the deleterious effects of chromium metal in soil.
\end{abstract}

Keywords: Chromium; Phytotoxicity; Hibiscus esculentus; Germination; Growth; Biochemical Attributes

\section{Introduction}

Heavy metals are the most imperative component of the environment that frequently accumulate in the soil due to unplanned municipal waste disposal, mining, use of extensive pesticides and chemical fertilizers [1,2]. Hyper accumulation of heavy metals may lead to toxic effect in human, animals, plants and other microorganisms and create a serious threat to biota and the environment [3].

Chromium is an environmental pollutant that ranks seventh in abundance within the earth crust [4]. Naturally occurring chromium in soil ranges from 10 to $50 \mathrm{mg} \cdot \mathrm{kg}^{-1}$ [1]. The chemistry of chromium is very complex. Its solubility, mobility and bioavailability in soil strongly depend on the various oxidation states from 0 to +6 . Depending on its oxidation state and concentration, chromium acts as a toxic or essential element for living organism. The two most common species of chromium are

${ }^{*}$ Corresponding author.
$\mathrm{Cr}(\mathrm{III})$ and $\mathrm{Cr}(\mathrm{VI})$ available in anionic form as chromate, dichromate and hydro chromate ions. $\mathrm{Cr}$ (III) is essential for animal and human at low concentration. Chromium is extremely stable in soil, but usually well immobilized on iron and manganese oxides and hydroxides or complexes to organic matter. The toxicity of $\mathrm{Cr}(\mathrm{VI})$ strongly depends on its concentration in the soil and its uptake mechanism [5]. The sources of chromium in environment are both natural and anthropogenic. Chromium is used on a large scale in many industries, including metallurgical, electroplating, production of paints and pigments, tanning, wood preservation, chromium chemicals production, pulp and paper production [6]. The leather industry is the major cause of high influx of chromium to the biosphere, accounting for $40 \%$ of the total industrial use [7]. Sewage and fertilizers are also the main sources of chromium [8]. These anthropogenic activities may lead to the widespread contamination in the environment $[9,10]$.

A high concentration of chromium was found to be 
harmful for plant life, reducing the protein contents, inhibiting the enzyme activity, and causing chlorosis and necrosis [11]. The chromium concentration in plant adversely affects several morphological and biochemical parameters [12]. Chromium toxicity interferes with several metabolic processes in plant, causing reduced seed germination or early seedling growth [13], biomass, photosynthetic impairing $[14,15]$. Phytotoxicity of chromium is considered inhibitory for plant growth. Its presence in surplus amount inside the plant can cause stunted growth [16-18]. The presence of chromium in soil disturbs the pattern of nutrient uptake in plant because of nutrient metal interaction $[19,20]$.

Phytotoxic effects of different chromium concentration on seed germination and seedling growth in various vegetable crops, Daucus carrota (L.), Raphanus sativus (L.), Beta vulgaris (L.), Lycopersium esculentum (L.) and Solanum melongena (L.), Vigna radiata (L.), Vigna angularis (L.), Lablab purpureus (L.), Lathyrus ordoratus (L.), Triticum aestivum (L.) were reported [21-23].

The present study was conducted to investigate the phytotoxic effects of different chromium concentration on Hibiscus esculentus (L.) to illustrate the potential of this species toward chromium metal stress.

\section{Material and Methods}

\subsection{Seed Material}

Certified seeds of Hibiscus esculentus (L.) were procured from Komal Seed Production, Tando Allahyar. Seeds of uniform size, color and weight were selected for experimental work.

\subsection{Soil Collection and Pot Preparation}

For pot experiment soil samples were collected from riverbed of Indus, Jamshoro. The soil (2 part sand and 1 part clay) was air dried for $2-3$ days. The pots were then filled with $5 \mathrm{~kg}$ air dried soil. The physicochemical properties of soil are given in Table 1.

\subsection{Chemicals and Stock Solution Preparation}

All chemicals used were of analytical reagent grade; an-

Table 1. Physico-chemical properties of initial soil samples*.

\begin{tabular}{cc}
\hline Soil Properties & Average Value \\
\hline $\mathrm{pH}$ & $7.15 \pm 0.005$ \\
$\mathrm{EC}(\mu \mathrm{S} / \mathrm{cm})$ & $486 \pm 0.577$ \\
$\mathrm{TDS}(\mathrm{mg} / \mathrm{L})$ & $233 \pm 0.577$ \\
Organic matter \% & $0.24 \pm 0.005$ \\
Moisture \% & $21.83 \pm 0.05$ \\
\hline
\end{tabular}

${ }^{*}$ Mean \pm S.D. $(n=3)$. hydrous potassium dichromate were procured from Fluka (Sigma-Aldrich, Madrid, Spain) and used without any further purification. Stock solution of chromium was prepared by dissolving $2.28 \mathrm{~g}$ of potassium dichromate in $1000 \mathrm{ml}$ of deionized water. The stock solution was then appropriately diluted to get the test solution of desired chromium concentration.

\subsection{Experimental Design}

A pot culture experiment was conducted at Green House of Institute of Plant Sciences, University of Sindh, Jamshoro. The experiment was arranged in complete randomized block design with three replicates for each treatment. To initiate the experiment under controlled condition, air dried soil artificially polluted with different concentration of potassium dichromate solution i.e. 0.5, 2.5, $5,10,25,50$ and $100 \mathrm{mg} \cdot \mathrm{kg}^{-1}$ respectively along with an untreated control. Chromium solution was uniformly mixed with air dried soil and kept for 2 weeks to stabilize (Figure 1).

\subsection{Seed Sterilization and Sowing}

Seed surface were sterilized with $0.1 \%$ mercuric chloride solution and then rinsed with deionized water [24]. Fifteen seeds were sown with uniform distance in each pot.

\subsection{Estimation of Germination and Growth Measurements}

The seed germination was noted for every 24 hour until the germination percentage was constant. For the evaluation of seedling growth 10 germinated seedlings of similar morphology were allowed to grow with concentration of $0.5,2.5,5,10,25,50$ and $100 \mathrm{mg} \cdot \mathrm{kg}^{-1}$ chromium in soil, irrigated on alternate day with distilled water. The

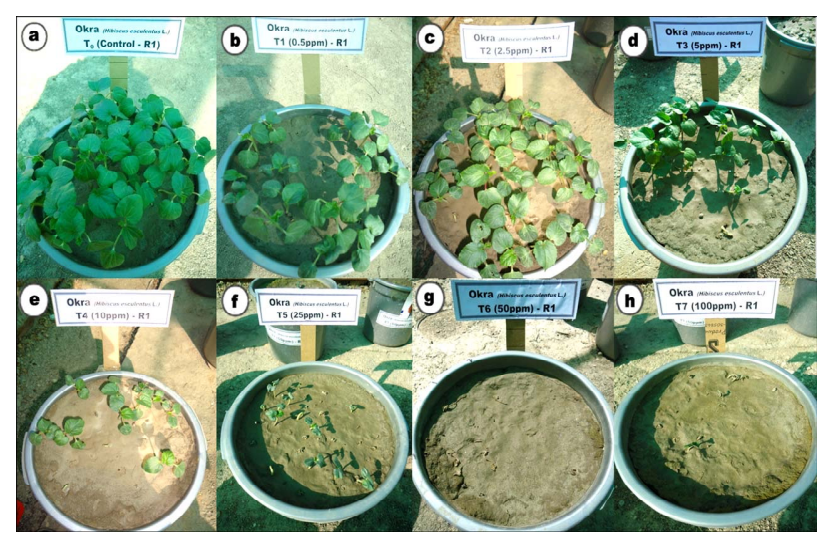

Figure 1. Pot experiment represents the phytotoxic effect of different chromium level in Hibiscus esculentus (L.) after 30 days: (a) Control (b) $0.5 \mathrm{mg} \cdot \mathrm{kg}^{-1}$ (c) $2.5 \mathrm{mg} \cdot \mathrm{kg}^{-1}$ (d) 5 $\mathrm{mg} \cdot \mathrm{kg}^{-1}$ (e) $10 \mathrm{mg} \cdot \mathrm{kg}^{-1}$ (f) $25 \mathrm{mg} \cdot \mathrm{kg}^{-1}$ (g) $50 \mathrm{mg} \cdot \mathrm{kg}^{-1}$ (h) 100 $\mathrm{mg} \cdot \mathrm{kg}^{-1}$. 
seedlings were harvested carefully after 30 days, washed with distilled water to remove soil particles and analyze for growth and various biochemical attributes. Growth attributes were studied in terms of root and shoot length $(\mathrm{cm})$, root and shoot fresh weight $(\mathrm{g})$, root and shoot dry weight (g). Seedlings were collected and cut at root-shoot junction and the length of their root and shoot were measured with a metric scale and expressed in centimeters [25]. The fresh weight of root and shoot samples were recorded on an analytical balance and expressed in gram per plant [26]. Later, plant parts were dried in an oven at $60^{\circ} \mathrm{C}$ for 24 hour to get constant dry weight for root and shoot.

\subsubsection{Germination Percentage}

The germination percentage is the proportion, expressed as percentage of germinated seeds to the total number of viable seeds that were tested by following formula: $[27,28]$.

$\% \mathrm{G}=$ (Number of germinated seeds/Total number of planted seeds) $\times 100$

\subsubsection{Seedling Vigor Index}

Seedling vigor index are those properties of the seed which determine the level of activity and performance of the seed during germination and seedling emergence. It is a single measurable property like germination describing several characteristics associated with various aspects of the performance of seed. Seedling vigor index is calculated by following formula: $[29,30]$

SVI $=$ Germination percentage $\times$ Seedling length

\subsubsection{Stress Tolerance Index}

Stress tolerance index is a useful tool for determining the high yield and stress tolerance potential of genotypes. Stress tolerance indices for different growth parameters were calculated using following formulae [31]:

RLSTI $=($ Root length of stress plant/Root length of control plant) $\times 100$

SLSTI $=($ Shoot length of stress plant/Shoot length of control plant) $\times 100$

RFSTI $=($ Root fresh weight of stress plant $/$ Root fresh weight of control plant $) \times 100$

SFSTI $=($ Shoot fresh weight of stress plant $/$ Shoot fresh weight of control plant $) \times 100$

RDSTI $=($ Root dry weight of stress plant $/$ Root dry weight of control plant $) \times 100$

SDSTI $=($ Shoot dry weight of stress plant/Shoot dry weight of control plant $) \times 100$

\subsection{Estimation of Biochemical Attributes}

Biochemical attributes were studied in term of photosynthetic pigments. The chlorophyll-a, chlorophyll-b and total chlorophyll $(a+b)$ were determined spectro-photo- metrically. Leaves were cut into small pieces, mixed thoroughly and $0.25 \mathrm{~g}$ of leaves was taken into a mortar to grind them finely by pestle with $25 \mathrm{ml}$ of $80 \%$ acetone for 5 minutes. The homogenate was filtered through filter paper (Whatman ${ }^{\circledR}$ No.42) and was made a volume of 25 $\mathrm{ml}$ with $80 \%$ acetone.

\section{Extract Monitoring by Spectrophotometer}

After the extraction, chlorophyll contents were monitored by UV-Vis spectrophotometer (Biochrom Libra S22). The optical density/absorbance of each solution was measured at 663 and $645 \mathrm{~nm}$ against $80 \%$ acetone blank in $1 \mathrm{~cm}$ quartz cuvette at room temperature. The Arnon's equation was used to calculate the amount of chlorophyll-a, chlorophyll-b and total chlorophyll $(\mathrm{a}+\mathrm{b})$ [32]:

$\mathrm{Chl} \mathrm{a}\left(\mathrm{mg} \cdot \mathrm{g}^{-1}\right)=[(12.7 \times \mathrm{A} 663)-(2.69 \times \mathrm{A} 645)] \times$ $\mathrm{ml}$ acetone/mg leaf tissue

$\mathrm{Chl} \mathrm{b}\left(\mathrm{mg} \cdot \mathrm{g}^{-1}\right)=[(22.9 \times \mathrm{A} 645)-(4.68 \times \mathrm{A} 663)] \times$ $\mathrm{ml}$ acetone/mg leaf tissue

$$
\text { Total Chl }=\mathrm{Chl} \mathrm{a}+\mathrm{Chl} \mathrm{b}
$$

\section{Statistical Analysis}

Data were statistically analyzed using one-way ANOVA on PASW ${ }^{\circledR}$ Statistics 18 (SPSS Inc., Chicago, IL, USA). The results are presented as means \pm S.E. (standard errors) and data from the different treatments and control were compared by Duncan's multiple-range test at $\mathrm{p}<$ 0.05 .

\section{Results and Discussion}

\subsection{Effect of Chromium Toxicity on Seed Germination}

The result of present study reveals that higher chromium concentration adversely influence the germination process of Hibiscus esculentus seeds (Figure 2). Chromium treatment at $0.5,2.5,5,10$ and $25 \mathrm{mg} \cdot \mathrm{kg}^{-1}$ has no significant $(p>0.05)$ effect on seed germination. However, germination percentage was significantly $(p<0.05)$ affected at 50 and $100 \mathrm{mg} \cdot \mathrm{kg}^{-1}$ by $42.22 \%$ and $48.88 \%$

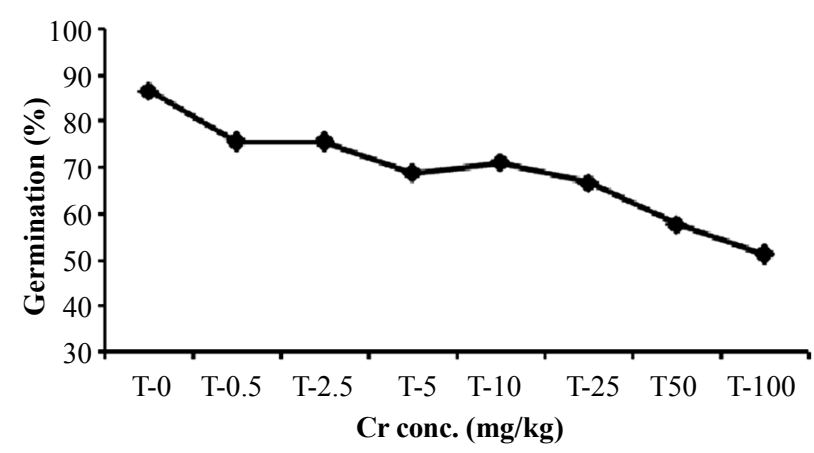

Figure 2. Effect of chromium on seed germination in $\mathrm{Hi}$ biscus esculentus (L.). 
reduction in germination (Table 2), indicating that higher level of chromium produced toxic effect in seed germination. Similar results were reported by Zayed and Terry [15]. Increasing concentration of heavy metal significantly reduce the strength of germination as compare to the lowest concentration of heavy metal which have the least harmful influence on the germination [33].

\subsection{Effect of Chromium Toxicity on Seedling Vigor Index}

The increased chromium level adversely influence the seedling vigor index of Hibiscus esculentus shown in Figure 3.

Seedling vigor index of Hibiscus esculentus gradually decrease with increase chromium concentration at 0.5 , $2.5,5,10,25$ and $50 \mathrm{mg} \cdot \mathrm{kg}^{-1}$ (Table 2). Various treatment of chromium were found to be toxic at sub optimal $\left(0.5 \mathrm{mg} \cdot \mathrm{kg}^{-1}\right.$ and $\left.2.5 \mathrm{mg} \cdot \mathrm{kg}^{-1}\right)$ to above optimal (5 - 100

Table 2. Effects of different chromium concentration on germination and seedling vigor index in Hibiscus esculents (L.)

\begin{tabular}{cccc}
\hline $\begin{array}{c}\text { Cr conc. } \\
\left(\mathbf{m g} \cdot \mathbf{k g}^{-1}\right)\end{array}$ & \% Germination & $\begin{array}{c}\text { \% Reduction in } \\
\text { Germination }\end{array}$ & SVI \\
\hline Control & $86.67^{\mathrm{a}} \pm 0.00$ & 13.33 & 1672.667 \\
0.5 & $75.56^{\mathrm{ab}} \pm 1.33$ & 24.44 & 1385.185 \\
2.5 & $75.56^{\mathrm{ab}} \pm 0.88$ & 24.44 & 1264.296 \\
5 & $68.89^{\mathrm{abc}} \pm 1.20$ & 31.11 & 1155.037 \\
10 & $71.11^{\mathrm{abc}} \pm 0.33$ & 28.88 & 941.037 \\
25 & $66.67^{\mathrm{abc}} \pm 2.08$ & 33.33 & 688.8889 \\
50 & $57.11^{\mathrm{bc}} \pm 0.33$ & 42.22 & 333.1852 \\
100 & $51.11^{\mathrm{c}} \pm 0.88$ & 48.88 & $\mathrm{ND}$ \\
\hline
\end{tabular}

*SVI = Seedling vigor index; ND = Not detected value. Number followed by the same letter in the same column are not significantly different according to Duncan Multiple Range Test at $\mathrm{p}<0.05$ level (Mean \pm S.E.). $\mathrm{mg} \cdot \mathrm{kg}^{-1}$ ) concentrations. The average seedling vigor index of Hibiscus esculentus reduce from 1672.66, 1385.18, $1264.29,1155.03,941.03,688.88$ and 333.18 respectively due to increase chromium level.

Similar results were reported by Ganesh et al. [34] that there was a reduction in vigor index in four genotypes of soybean at $5-200 \mathrm{mg} \cdot \mathrm{L}^{-1}$ concentration of chromium, with respect to control application.

\subsection{Chromium Toxicity on Root and Shoot Elongation}

The results after $30^{\text {th }}$ day exposure of chromium to $\mathrm{Hi}$ biscus esculentus, shows considerable reduction in root and shoot elongation. The length of Hibiscus esculentus was adversely affected due to chromium (Table 3). The average root length $8.66 \pm 0.33,8.23 \pm 0.12,8.10 \pm 0.10$ was not significantly $(\mathrm{p}>0.05)$ affected at $0.5,2.5$ and 5 $\mathrm{mg} \cdot \mathrm{kg}^{-1}$ respectively. Although root elongation was significantly $(\mathrm{p}<0.05)$ reduce at 10,25 and $50 \mathrm{mg} \cdot \mathrm{kg}^{-1}$ by $6.40 \pm 1.13,5.23 \pm 0.99$ and $2.43 \pm 0.06$ respectively. Similarly, the average shoot length of Hibiscus esculentus $9.66 \pm 0.66,8.50 \pm 1.32,8.66 \pm 0.44$ was not significantly affected $(\mathrm{p}>0.05)$ at $0.5,2.5$ and $5 \mathrm{mg} \cdot \mathrm{kg}^{-1}$ respectively. However, increase in chromium 10, 25, and

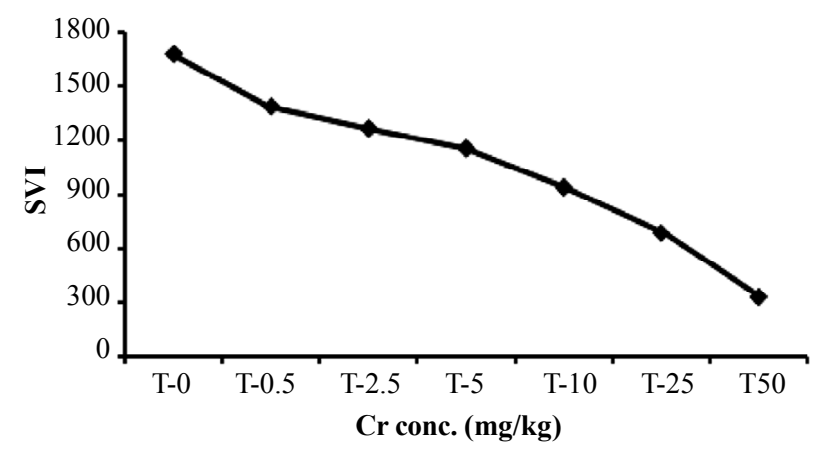

Figure 3. Effect of chromium on seedling vigor index in $\mathrm{Hi}$ biscus esculentus (L.).

Table 3. Effects of different chromium concentration on seedling growth of Hibiscus esculentus (L.).

\begin{tabular}{ccccccc}
\hline Cr conc. $\left(\mathbf{m g} \cdot \mathbf{k g}^{-1}\right)$ & RL $(\mathbf{c m})$ & SL $(\mathbf{c m})$ & RFW (g) & SFW (g) & RDW (g) & SDW (g) \\
\hline Control & $9.30^{\mathrm{a}} \pm 0.51$ & $10.00^{\mathrm{a}} \pm 0.00$ & $0.21^{\mathrm{a}} \pm 0.03$ & $0.83^{\mathrm{a}} \pm 0.06$ & $0.07^{\mathrm{a}} \pm 0.02$ & $0.11^{\mathrm{a}} \pm 0.02$ \\
0.5 & $8.66^{\mathrm{a}} \pm 0.33$ & $9.66^{\mathrm{a}} \pm 0.66$ & $0.19^{\mathrm{ab}} \pm 0.02$ & $0.80^{\mathrm{a}} \pm 0.16$ & $0.07^{\mathrm{a}} \pm 0.02$ & $0.11^{\mathrm{a}} \pm 0.02$ \\
2.5 & $8.23^{\mathrm{ab}} \pm 0.12$ & $8.50^{\mathrm{ab}} \pm 1.32$ & $0.19^{\mathrm{ab}} \pm 0.03$ & $0.75^{\mathrm{a}} \pm 0.14$ & $0.05^{\mathrm{ab}} \pm 0.00$ & $0.09^{\mathrm{a}} \pm 0.02$ \\
5 & $8.10^{\mathrm{ab}} \pm 0.10$ & $8.66^{\mathrm{ab}} \pm 0.44$ & $0.16^{\mathrm{ab}} \pm 0.03$ & $0.70^{\mathrm{ab}} \pm 0.09$ & $0.04^{\mathrm{ab}} \pm 0.00$ & $0.09^{\mathrm{a}} \pm 0.01$ \\
10 & $6.40^{\mathrm{bc}} \pm 1.13$ & $6.83^{\mathrm{bc}} \pm 0.41$ & $0.16^{\mathrm{ab}} \pm 0.03$ & $0.39^{\mathrm{bc}} \pm 0.00$ & $0.03^{\mathrm{ab}} \pm 0.00$ & $0.05^{\mathrm{a}} \pm 0.00$ \\
25 & $5.23^{\mathrm{c}} \pm 0.99$ & $5.10^{\mathrm{cd}} \pm 1.45$ & $0.13^{\mathrm{ab}} \pm 0.00$ & $0.31^{\mathrm{c}} \pm 0.13$ & $0.03^{\mathrm{ab}} \pm 0.01$ & $0.05^{\mathrm{ab}} \pm 0.02$ \\
50 & $2.43^{\mathrm{d}} \pm 0.06$ & $3.33^{\mathrm{d}} \pm 0.16$ & $0.11^{\mathrm{b}} \pm 0.01$ & $0.14^{\mathrm{c}} \pm 0.01$ & $0.01^{\mathrm{b}} \pm 0.00$ & $0.02^{\mathrm{b}} \pm 0.00$ \\
\hline
\end{tabular}

"RL = Root length; SL = Shoot length; RFW = Root fresh weight; SFW = Shoot fresh weight; RDW = Root dry weight; SDW = Shoot dry weight. Numbers followed by the same letter in the same column are not significantly different according to Duncan Multiple Range Test at $p<0.05$ level (Mean \pm S.E.) 
$50 \mathrm{mg} \cdot \mathrm{kg}^{-1}$ significantly $(\mathrm{p}<0.05)$ reduced shoot length with respect to control plant by $6.83 \pm 0.41,5.10 \pm 1.45$ and $3.33 \pm 0.16$ respectively. No data were found in 100 $\mathrm{mg} \cdot \mathrm{kg}^{-1}$ soil treatment because all plants were died at seedling stage, indicating that higher level of chromium significantly $(\mathrm{p}<0.05)$ affected root and shoot elongation in Hibiscus esculentus. Several author reported that the inhibition of root length caused by heavy metals may be due to metal interference with cell division, together with inducement of chromosomal aberrations and irregular mitosis $[35,36]$, which can be effected on seedling growth. Samantaray et al. [37] in a study by means of chromite mine pollute soil in five mung bean cultivars, noted that root growth was significantly affected $28^{\text {th }}$ days after root emergence as seedling are more sensitive than seed germination for measurement of the toxic effect of chromium pollution.

\subsection{Effect of Chromium Toxicity on Root and Shoot Fresh Weight}

The root and shoot fresh weight of Hibiscus esculentus were severely affected due to increase chromium concentration in soil (Table 3). Result shows that chromium treatment at $0.5,2.5,5,10$ and $25 \mathrm{mg} \cdot \mathrm{kg}^{-1}$ was not significantly $(\mathrm{p}>0.05)$ affect root fresh weight by $0.19 \pm 0.02$, $0.19 \pm 0.03,0.16 \pm 0.03,0.16 \pm 0.03,0.13 \pm 0.00$ respectively. However, the root fresh weight of Hibiscus esculentus was significantly $(\mathrm{p}<0.05)$ affected at 50 $\mathrm{mg} \cdot \mathrm{kg}^{-1}$ by $0.11 \pm 0.01$. Similarly, at $0.5,2.5,5$ and 10 $\mathrm{mg} \cdot \mathrm{kg}^{-1}$ the shoot fresh weight of Hibiscus esculentus was not significantly ( $p>0.05$ ) affected by $0.80 \pm 0.16$, $0.75 \pm 0.14,0.70 \pm 0.09$ respectively. Although, the shoot fresh weight of Hibiscus esculentus was significantly $(\mathrm{p}<0.05)$ decrease at 10,25 and $50 \mathrm{mg} \cdot \mathrm{kg}^{-1}$ by $0.39 \pm 0.00,0.31 \pm 0.13,0.14 \pm 0.01$ respectively. Similar results were reported by Fozia et al. [38] on a gradual decrease of root and shoot fresh weight in Helianthus annus (L.) with increase in chromium level. The toxic effect of chromium on the root and shoot fresh weight in eight-day old seedling of Brassica oleracea (L.) var. acephala DC (kale) were reported by Ozdener et al. [39], treated with various concentrations of chromium in the growth medium.

\subsection{Effect of Chromium Toxicity on Root and Shoot Dry Weight}

The root and shoot dry weight of Hibiscus esculentus were decrease with an increase in chromium level (Table 3). Result shows that at $0.5,2.5,5,10$ and $5 \mathrm{mg} \cdot \mathrm{kg}^{-1}$ chromium produced no significant $(p>0.05)$ effect on root dry weight $0.07 \pm 0.02,0.05 \pm 0.00,0.04 \pm 0.00$, $0.03 \pm 0.00,0.03 \pm 0.01$ respectively. The root dry weight of Hibiscus esculentus was significantly ( $p<$
0.005 ) affected at $50 \mathrm{mg} \cdot \mathrm{kg}^{-1}$ by $0.01 \pm 0.00$. Similarly, the average shoots dry weight of Hibiscus esculentus $0.11 \pm 0.02,0.09 \pm 0.02,0.09 \pm 0.01,0.05 \pm 0.00,0.05 \pm$ 0.02 was not significantly $(\mathrm{p}>0.05)$ affect at $0.5,2.5,5$, 10 and $25 \mathrm{mg} \cdot \mathrm{kg}^{-1}$ respectively. Although the dry weight of shoot was significantly $(\mathrm{p}<0.05)$ affected at 50 $\mathrm{mg} \cdot \mathrm{kg}^{-1}$ by $0.02 \pm 0.00$. It was reported by Ganesh et al. [40] that there was a reduction in growth, dry weight in four genotypes of soybean at $5-200 \mathrm{mg} \cdot \mathrm{L}^{-1}$ concentration of chromium, with respect to control application. In a study conducted on Vallisneria spiralis to evaluate the chromium accumulation and toxicity in relation to biomass production, Vajpayee et al. [41] was found that dry matter production affected by chromium concentration above $2.5 \mathrm{~m} \cdot \mathrm{L}^{-1} \mathrm{Ag}$ in nutrient medium.

\subsection{Effect of Chromium Toxicity on Chlorophyll Contents}

The effects of chromium on photosynthetic pigments of Hibiscus esculentus leaves were determined on $30^{\text {th }}$ day (Table 4). The photosynthetic pigment chlorophyll-a, chlorophyll-b and total chlorophyll of Hibiscus esculentus were decrease with increased chromium treatments (Figure 4). The chlorophyll-a in Hibiscus esculentus leaves were significantly $(\mathrm{p}<0.05)$ decrease from $5.36 \pm$ $0.05,4.81 \pm 0.04,4.43 \pm 0.05,2.24 \pm 0.06,0.22 \pm 0.00$ and $0.19 \pm 0.01$ respectively. Similarly, the chlorophyll-b in Hibiscus esculentus leaves were decrease significantly ( $\mathrm{p}<0.05$ ) from $8.73 \pm 0.00,3.55 \pm 0.00,3.47 \pm 0.00$, $1.68 \pm 0.02,1.41 \pm 0.01$, and $1.18 \pm 0.00$ respectively. The total chlorophyll content significantly $(\mathrm{p}<0.05)$ affected at high chromium concentration from $14.09 \pm 0.05$, $8.37 \pm 0.04,7.90 \pm 0.05,3.92 \pm 0.07,1.64 \pm 0.01$, and $1.38 \pm 0.01$ respectively. Some other studies have the same conclusion that the chlorophyll contents were decrease if kept under $\mathrm{Cr} 6+$ stress $\left(10-40 \mathrm{mg} \mathrm{L}^{-1}\right)$ [34].

Table 4. Effect of different chromium concentration on chlorophyll contents (a, b, total) in Hibiscus esculentus (L.).

\begin{tabular}{cccc}
\hline $\begin{array}{c}\text { Cr conc. } \\
\left(\mathbf{m g} \cdot \mathbf{k g}^{-1}\right)\end{array}$ & $\begin{array}{c}\text { Chl. a } \\
\left(\mathbf{m g} \cdot \mathbf{g}^{-1} \mathbf{f . w t} .\right)\end{array}$ & $\begin{array}{c}\text { Chl. b } \\
\left(\mathbf{m g} \cdot \mathbf{g}^{-1} \mathbf{f . w t} .\right)\end{array}$ & $\begin{array}{c}\text { Total Chl. } \\
\left(\mathbf{m g} \cdot \mathbf{g}^{-1} \mathbf{f . w t} .\right)\end{array}$ \\
\hline Control & $5.71^{\mathrm{a}} \pm 0.03$ & $9.13^{\mathrm{a}} \pm 0.00$ & $14.85^{\mathrm{a}} \pm 0.03$ \\
0.5 & $5.36^{\mathrm{b}} \pm 0.05$ & $8.73^{\mathrm{b}} \pm 0.00$ & $14.09^{\mathrm{b}} \pm 0.05$ \\
2.5 & $4.81^{\mathrm{c}} \pm 0.04$ & $3.55^{\mathrm{c}} \pm 0.00$ & $8.37^{\mathrm{c}} \pm 0.04$ \\
5 & $4.43^{\mathrm{d}} \pm 0.05$ & $3.47^{\mathrm{d}} \pm 0.00$ & $7.90^{\mathrm{d}} \pm 0.05$ \\
10 & $2.24^{\mathrm{e}} \pm 0.06$ & $1.68^{\mathrm{e}} \pm 0.02$ & $3.92^{\mathrm{e}} \pm 0.07$ \\
25 & $0.22^{\mathrm{f}} \pm 0.00$ & $1.41^{\mathrm{f}} \pm 0.01$ & $1.64^{\mathrm{f}} \pm 0.01$ \\
50 & $0.19^{\mathrm{f}} \pm 0.01$ & $1.18^{\mathrm{g}} \pm 0.00$ & $1.38^{\mathrm{g}} \pm 0.01$ \\
\hline
\end{tabular}

*Number followed by the same letter in the same column are not significantly different according to Duncan Multiple Range Test at $\mathrm{p}<0.05$ level (Mean \pm S.E.). 
The studies indicate that heavy metals and metalloids have effects on chlorophyll and amino acid content in plants. Heavy metals are known to interfere with chlorophyll synthesis either through direct inhibition of an enzymatic step or by inducing deficiency of an essential nutrient [42].

\subsection{Effect of Chromium on Tolerance Index}

The result shows that increasing level of chromium lower the percentage tolerance in Hibiscus esculentus (Table 5, Figure 5). The root length of Hibiscus esculentus at different chromium treatment $0.5,2.5,5,10,25$ and 50 $\mathrm{mg} \cdot \mathrm{kg}^{-1}$ has $93.18 \%, 88.53 \%, 87.09 \%, 68.81 \%, 56.27 \%$ and $26.16 \%$ of tolerance respectively. The highest value (93.18\%) of RLSTI was recorded at $0.5 \mathrm{mg} \cdot \mathrm{kg}^{-1}$ and the lowest $(26.16 \%)$ at $50 \mathrm{mg} \cdot \mathrm{kg}^{-1}$ respectively. Similarly, tolerance level of shoot length in Hibiscus esculentus was decreased from $96.66 \%, 85 \%, 86.66 \%, 68.33 \%$, $51 \%$ and $33.33 \%$ respectively due to increased chromium level. The maximum SLSTI value $(96.66 \%)$ was recorded at $0.5 \mathrm{mg} \cdot \mathrm{kg}^{-1}$ and the lowest $(33.33 \%)$ at 50 $\mathrm{mg} \cdot \mathrm{kg}^{-1}$ respectively.

The RFSTI of Hibiscus esculentus was decrease as chromium level increased in the soil from $89.06 \%$,

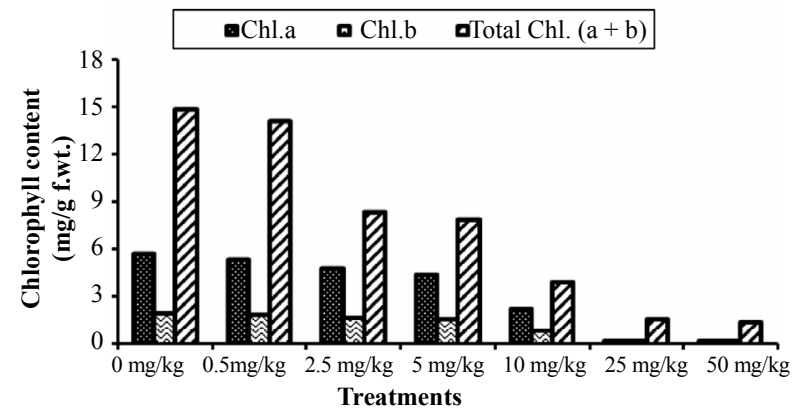

Figure 4. Effect of chromium on chlorophyll content in $\mathbf{H i}$ biscus esculentus (L.).
$89.06 \%, 78.12 \%, 76.56 \%, 60.93 \%$ and $51.56 \%$ respectively. The highest value $(89.06 \%)$ for RFSTI was recorded at $0.5 \mathrm{mg} \cdot \mathrm{kg}^{-1}$ and the lowest value $(51.56 \%)$ at 50 $\mathrm{mg} \cdot \mathrm{kg}^{-1}$ respectively. Similarly, the SFSTI of Hibiscus esculentus.was also decreased from 96.01\%, 90.43\%, $83.66 \%, 47.41 \%, 37.45 \%$ and $16.73 \%$ respectively. The maximum value for SFSTI $(96.01 \%)$ was recorded at 0.5 $\mathrm{mg} \cdot \mathrm{kg}^{-1}$ and the lowest value $(16.73 \%)$ at $50 \mathrm{mg} \cdot \mathrm{kg}^{-1} \mathrm{re}-$ spectively.

The dry matter stress tolerance index (DMSTI) of $\mathrm{Hi}$ biscus esculentus was adversely affected with chromium application. The RDSTI of Hibiscus esculentus was decreased from $100 \%, 68.18 \%, 59.09 \%, 50 \%, 40.09 \%$ and $22.72 \%$ respectively. Maximum value for RDSTI (100\%) was noted at $0.5 \mathrm{mg} \cdot \mathrm{kg}^{-1}$ and the lowest value $(22.72 \%)$ at $50 \mathrm{mg} \cdot \mathrm{kg}^{-1}$ was recorded. Similarly, the SDSTI of $\mathrm{Hi}$ biscus esculentus was also decreased from 97.14\%, $82.85 \%, 82.85 \%, 48.57 \%, 42.85 \%$ and $17.14 \%$ respectively. The maximum SDSTI value $(97.14 \%)$ was recorded at $0.5 \mathrm{mg} \cdot \mathrm{kg}^{-1}$ and the lowest value $(17.14 \%)$ at $50 \mathrm{mg} \cdot \mathrm{kg}^{-1}$ was recorded. A study on stress tolerance suggests that mechanism of tolerance helps plant to maintain growth even in the presence of potentially toxic metal concentrations $[43,44]$ used the root and shoot

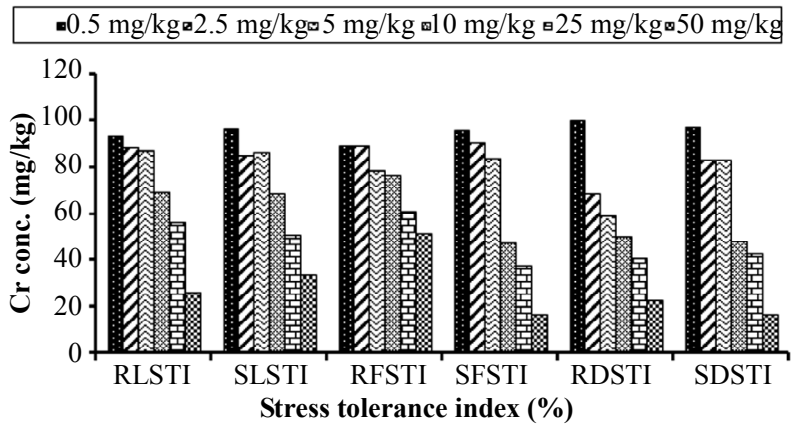

Figure 5. Effect of chromium on stress tolerance index (\%) in Hibiscus esculentus (L.).

Table 5. Stress tolerance index (\%) of Hibiscus esculentus (L.) grown in different treatments of chromium contaminated soil.

\begin{tabular}{|c|c|c|c|c|c|c|c|}
\hline \multirow{2}{*}{ Treatments } & \multirow{2}{*}{$\begin{array}{l}\text { Cr concentration } \\
\text { in soil }\left(\mathrm{mg} \cdot \mathrm{kg}^{-1}\right)\end{array}$} & \multicolumn{6}{|c|}{ Stress tolerance index (\%) } \\
\hline & & RLSTI & SLSTI & RFSTI & SFSTI & RDSTI & SDSTI \\
\hline $\mathrm{T}_{0}$ & Control & 0.00 & 0.00 & 0.00 & 0.00 & 0.00 & 0.00 \\
\hline $\mathrm{T}_{1}$ & 0.5 & 93.18 & 96.66 & 89.06 & 96.01 & 100 & 97.14 \\
\hline $\mathrm{T}_{2}$ & 2.5 & 88.53 & 85 & 89.06 & 90.43 & 68.18 & 82.85 \\
\hline $\mathrm{T}_{3}$ & 5 & 87.09 & 86.66 & 78.12 & 83.66 & 59.09 & 82.85 \\
\hline $\mathrm{T}_{4}$ & 10 & 68.81 & 68.33 & 76.56 & 47.41 & 50 & 48.57 \\
\hline $\mathrm{T}_{5}$ & 25 & 56.27 & 51 & 60.93 & 37.45 & 40.09 & 42.85 \\
\hline $\mathrm{T}_{6}$ & 50 & 26.16 & 33.33 & 51.56 & 16.73 & 22.72 & 17.14 \\
\hline
\end{tabular}

${ }^{*}$ RLSTI = Root length stress tolerance index; SLSTI = Shoot length stress tolerance index; RFSTI = Root fresh weight stress tolerance index; SFSTI = Shoot fresh weight stress tolerance index; RDSTI = Root dry weight stress tolerance index; SDSTI Shoot dry weight stress tolerance index. 
growth as an important parameter in classification of heavy metal tolerance.

Decrease in fresh weight because of low water uptake may be due to subsequent membrane damage since plant cell membrane generally considered as the primary sites of metal injury [45]. The negative effect of chromium on tolerance indices of fresh and dry weight was also determined within rice [46].

\section{Conclusion}

The toxic effect of heavy metal on plant growth depends on the amount of toxic metal taken up from the specified environment. The extensive use of chromium in a large number of products and industrial process has resulted in severe environmental contamination. Chromium toxicity has become significant due to its constant increase in the environment. Increasing concentration of chromium metal significantly inhibits seed germination, growth and biochemical attribute of Hibiscus esculentus. The overall inhibitory effect of chromium calculated as tolerance index which was more pronounced in Hibiscus esculentus seedlings. This information can be considered a contributing step in exploring and finding the tolerance limit of Hibiscus esculentus at different concentration of chromium. Results of the study are useful indicators of chromium tolerance to some extent for plantation of Hibiscus esculentus in chromium contaminated areas. However, in the toxic metal contaminated areas, further research is needed to determine the effect of different level of metals in the environment and various parts of the plant.

\section{Acknowledgements}

The authors would like to thank Institute of Plant Sciences, University of Sindh, Jamshoro, Pakistan for providing technical assistance of this work.

\section{REFERENCES}

[1] S. K. Pandey and S. K. Pandey, "Germination and Seedling Growth of Field Pea Pisum sativum Malviya Matar15 (HUDP-15) and Pusa Prabhat (DDR-23) under Varying Level of Copper and Chromium," American Journal of Science, Vol. 4, No. 3, 2008, pp. 28-40.

[2] M. Paksoy and B. Acar, "Effect of Organic Fertilizers on Yield Components of Some Tomato Cultivars," Asian Journal of Chemistry, Vol. 21, No. 8, 2009, pp. 60416047.

[3] T. Y. Nodelkoska and P. M. Doran, "Interactive Effects of Temperature and Metal Stress on the Growth and Some Biochemical Compounds in Wheat Seedlings," Environmental Pollution, Vol. 107, No. 3, 2000, pp. 315320. http://dx.doi.org/10.1016/S0269-7491(99)00177-3

[4] P. Chandra, S. Sinha and U. N. Rai, "Bioremediation of Chromium from Water and Soil by Vascular Aquatic
Plants," ACS Symposium, Series 664, 1997, pp. 274-282.

[5] J. L. Gardea Torresdey, G. de la Rosa, J. R. Peralta-Videa and M. Montes, "A Study of the Differential Uptake and Transportation of Trivalent and Hexavalent Chromium by Tumbleweed (Salsola kali)," Archives of Environmental Contamination and Toxicology, Vol. 48, No. 2, 2005, pp. 225-232. http://dx.doi.org/10.1007/s00244-003-0162-x

[6] P. B. Salunkhe, P. K. Dhakephalkar and K. M. Paknikar, "Bioremediation of Hexavalent $\mathrm{Cr}$ in Soil Microcosms," Biotechnology Letters, Vol. 20, No. 8, 1998, pp. 749-751. http://dx.doi.org/10.1023/A:1005338820430

[7] J. Barnhart, "Occurrences, Uses, and Properties of Chromium," Regulatory Toxicology and Pharmacology, Vol. 26, No. 1, 1997, pp. 3-7. http://dx.doi.org/10.1006/rtph.1997.1132

[8] A. E. Pillay, J. R. Williams, M. O., E. L Mardi, S. M. H., Al-Lawati, M. H. Al-Hadabbi and A. Al-Hamdi, "Risk Assessment of Chromium and Arsenic in Date Palm Leaves Used as Livestock Feed," Environment International, Vol. 29, No. 5, 2003, pp. 541-545.

[9] D. E. Kimbrough, Y. Cohen, A. M. Winer, L. Creelman and C. Mabuni, "A Critical Assessment of Chromium in the Environment," Critical Reviews in Environmental Science and Technology, Vol. 29, No. 1, 1999, pp. 1-46. http://dx.doi.org/10.1080/10643389991259164

[10] J. Kotas and Z. Stasicka, "Commentary: Chromium Occurrence in the Environment and Methods of Its Speciation," Environmental Pollution, Vol. 107, No. 3, 2000, pp. 263-283. http://dx.doi.org/10.1016/S0269-7491(99)00168-2

[11] A. K. Pendias and H. Pendias, "Trace Elements in Soils and Plants," CRC Press, Boca Raton, 2001, p. 253.

[12] B. K. Dube, K. Tewari, J. Chatterjee and C. Chatterjee, "Excess Chromium Alters Uptake and Translocation of Certain Nutrients in Citrullus," Chemosphere, Vol. 53, No. 9, 2003, pp. 1147-1153. http://dx.doi.org/10.1016/S0045-6535(03)00570-8

[13] K. Nath, S. Saini and Y. K. Sharma, "Chromium in Tannery Industry Effluent and Its Effect on Plant Metabolism and Growth," Journal of Environmental Biology, Vol. 26, No. 2, 2005, pp. 197-204.

[14] Y. Du, J. H. He, J. J. Chen, X. G. Wei, X. Q. Yang, S. Y. Wang and W. B. He, "Effects of Heavy Metals of Pb, Cd and $\mathrm{Cr}$ on the Growth of Vegetables and Their Uptake," Acta Horticulturae Sinica, Vol. 30, No. 1, 2003, pp. 5155.

[15] A. M. Zayed and N. Terry, "Chromium in the Environment: Factors Affecting Biological Remediation," Plant and Soil, Vol. 249, 1, 2003, 139-156. http://dx.doi.org/10.1023/A:1022504826342

[16] N. R. Bishnoi, A. Dua, V. K. Gupta and S. K. Sawhney, "Effect of Chromium on Seed Germination, Seedling Growth and Yield of Peas," Agriculture, Ecosystems and Environment, Vol. 47, No. 1, 1993, pp. 47-57. http://dx.doi.org/10.1016/0167-8809(93)90135-C

[17] S. Citterio, A. Santagostino, P. Fumagalli Prato, N. P. Ranalli and S. Sgorbati, "Heavy Metal Tolerance and Accumulation of $\mathrm{Cd}, \mathrm{Cr}$ and $\mathrm{Ni}$ by Cannabis sativa L.," 
Plant and Soil, Vol. 256, No. 2, 2003, pp. 243-252. http://dx.doi.org/10.1023/A:1026113905129

[18] M. Faisal and S. Hasnain, "Chromate Resistant Bacillus cereus Augments Sunflower Growth by Reducing Toxicity Cr (VI)," Journal of Plant Biology, Vol. 48, No. 2, 2005, pp. 187-194.

http://dx.doi.org/10.1007/BF03030407

[19] M. B. Mc Bride, B. K. Richards and T. Steenbuls, "Bioavailability and Crop Uptake of Trace Elements in Soil Columns Amended with Sewage Sludge Products," Plant and Soil, Vol. 262, No. 1-2, 2004, pp. 71-84. http://dx.doi.org/10.1023/B:PLSO.0000037031.21561.34

[20] M. Zupancic, N. Bukovec, R. Milacio and J. Scancer, "Comparison of Various Phosphate Stabilization Agents for the Immobilization of $\mathrm{Ni}$ and $\mathrm{Zn}$ in Sewage Sludge," Water, Air and Soil Pollution, Vol. 156, No. 1, 2004, pp. 57-69.

http://dx.doi.org/10.1023/B:WATE.0000036789.07619.b $\underline{6}$

[21] S. Lakshmi and P. Sundaramoorthy, "Effect of Chromium on Germination and Seedling Growth of Vegetable Crops," Asian Journal of Science and Technology, Vol. 1, 2010, pp. 28-31.

[22] R. Jun, T. Ling and Z. Guanghua, "Effects of Chromium on Seed Germination, Root Elongation and Coleoptile Growth in Six Pulses," International Journal of Environmental Science and Technology, Vol. 6, No. 4, 2009, pp. 571-578. http://dx.doi.org/10.1007/BF03326097

[23] R. S. Isak, R. S. Parveen, A. S. Rafique and A. S. Alamgir, "Phytotoxic Effects of Heavy Metals (Cr, Cd, Mn and $\mathrm{Zn}$ ) on Wheat (Triticum aestivum L.) Seed Germination and Seedlings Growth in Black Cotton Soil of Nanded, India," Research Journal of Chemical Sciences, Vol. 3, No. 6, 2013, pp. 14-23.

[24] V. Ramasubramanian, N. Kannan and V. Ravichandran, "Analysis of Industrial Effluents and Their Impact on the Growth and Metabolism of Phaseolus mungo L." Communications in Soil Science and Plant Analysis, Vol. 24, No. 17-18, 1993, pp. 2241-2249. http://dx.doi.org/10.1080/00103629309368952

[25] C. H. Chou and H. J. Lin, "Autointoxication Mechanism of Oriza sativa L. Phytotoxic Effects of Decomposing Rice Residues in Soil," Journal of Chemical Ecology, Vol. 2, No. 3, 1976, pp. 353-367. http://dx.doi.org/10.1007/BF00988282

[26] D. S. Bush, "Calcium Regulation in Plant Cells and Its Role in Signaling," Annual Review of Plant Biology, Vol. 46, 1995, pp. 95-122. http://dx.doi.org/10.1146/annurev.pp.46.060195.000523

[27] I. E. Akinci and S. Akinci, "Effect of Chromium Toxicity on Germination and Early Seedling Growth in Melon (Cucumis melo L.)," African Journal of Biotechnology, Vol. 9, No. 29, 2010, pp. 4589-4594. http://www.ajol.info/index.php/ajb/issue/view/9571

[28] S. J. Scott, R. A. Jones and W. A. William, "Review of Data Analysis Methods for Seed Germination," Crop Science, Vol. 24, No. 6, 1984, pp. 1192-1199. http://dx.doi.org/10.2135/cropsci1984.0011183X0024000 $\underline{60043 x}$
[29] A. Abdul Baki and J. D. Anderson, "Vigour Determination in Soybean Seed by Multiple Criteria," Crop Science, Vol. 13, No. 6, 1993, pp. 630-633. http://dx.doi.org/10.2135/cropsci1973.0011183X0013000 $\underline{60013 x}$

[30] J. D. Bewly and B. M. Black, "Physiology and Biochemistry of Seeds in Relation to Germination," Springer Verlag, New York, 1982, pp. 40-80. http://dx.doi.org/10.1007/978-3-642-68643-6

[31] D. A. Wilkins, "A technique for Measurement of Lead Tolerance in Plants," Nature, Vol. 180, No. 4575, 1957, pp. 37-38. http://dx.doi.org/10.1038/180037b0

[32] D. I. Arnon, "Copper Enzymes in Isolated Chloroplasts, Polyphenol Oxidase in Beta vulgaris," Plant Physiology, Vol. 24, 1949, pp. 1-15. http://dx.doi.org/10.1104/pp.24.1.1

[33] J. R. Peralta, J. L. Gardea Torresdey, K. J. Tiemann, E. Gomez, S. Arteaga and E. Rascon, "Uptake and Effects of Five Heavy Metals on Seed Germination and Plant Growth in Alfalfa (Medicago sativa L.)," Bulletin of Environmental Contamination and Toxicology, Vol. 66, No. 6, 2001, pp. 727-734.

[34] D. Yang, G. Shi and D. Song, "The Resistant Reaction of Brasentia Scheberi Winter-Bud to Cr (VI) Pollution," Journal of Lake Sciences, Vol. 13, No. 2, 2001, pp. 169-174.

[35] W. Jiang, D. Liu and X. Liu, "Effects of Copper on Root Growth, Cell Division and Nucleolus of Zea mays," Plant Biology, Vol. 44, No. 1, 2001, pp. 105-109. http://dx.doi.org/10.1023/A:1017982607493

[36] D. Liu, W. Jiang and X. Gao, "Effect of Cadmium on Root Growth, Cell Division and Nucleoli in Root Tip Cells of Garlic," Plant Biology, Vol. 47, No. 1, 2003, pp. 79-83.

[37] S. Samantaray, G. R. Rout and P. Das, "Studies on Differential Tolerance of Mung Bean Cultivars to Metalliferous Minewastes," Agribiological Research, Vol. 52, No. 3-4, 1999, pp. 193-201.

[38] A. Fozia, A. Z. Muhammad and M. K. Zafar, "Effect of Chromium on Growth Attributes in Sunflower (Helianthus annuus L.)," Journal of Environmental Sciences, Vol. 20, No. 12, 2008, pp. 1475-1480. http://dx.doi.org/10.1016/S1001-0742(08)62552-8

[39] Y. Ozdener, B. K. Aydin, S. Fatma Aygun and F. Yurekli, "Effect of Hexavalent Chromim on the Growth and Physiologicl and Biochemical Parameters on Brassica oleracea L. var. acephala DC," Acta Biologica Hungarica, Vol. 62, No. 4, 2011, pp. 463-476. http://dx.doi.org/10.1556/ABiol.62.2011.4.11

[40] K. S. Ganesh, L. Baskaran, A. A. Chidambaram and P. Sundaramoorthy, "Influence of Chromium Stress on proline Accumulation in Soybean (Glycine max L. Merr.) Genotypes," Global Journal of Environmental Research, Vol. 3, No. 2, 2009, pp. 106-108.

[41] P. Vajpayee, U. N. Rai, M. B. Ali, R. D. Tripathi, V. Yadav and S. Sinha, "Chromium Induced Physiological changes in Vallisneria spiralis L. and its role in phytoreMediation of Tannery Effluent," Bulletin of Environmental Contamination and Toxicology, Vol. 67, No. 2, 2001, pp. 
246-256.

[42] F. Van Assche and H. Clijsters, "Multiple Effects of Heavy Metals on Photosynthesis," In: R. Marcelle, Ed., Effects of Stress on Photosynthesis, Nijhoff/Junk, The Hague, 1983, pp. 371-382. http://dx.doi.org/10.1007/978-94-009-6813-4_39

[43] S. Clemens, "Toxic Metal Accumulation, Responses to Exposure and Mechanisms of Tolerance in Plants," Biochimie, Vol. 88, No. 11, 2006, pp. 1707-1719. http://dx.doi.org/10.1016/j.biochi.2006.07.003

[44] H. Diwan, I. Khan, A. Ahmad and M. Iqbal, "Induction of Phytochelatins and Antioxidant Defence System in Brassica juncea and Vigna radiata in Response to Chromium
Treatments," Plant Growth Regulation, Vol. 61, No. 1, 2010, pp. 97-107.

http://dx.doi.org/10.1007/s10725-010-9454-0

[45] J. Barcelo and C. Poschenrieder, "Plant-Water Relations as Affected by Heavy Metal Stress: A Review," Journal of Plant Nutrition, Vol. 13, No. 1, 1990, pp. 1-37. http://dx.doi.org/10.1080/01904169009364057

[46] S. K. Panda, "Chromium-Mediated Oxidative Stress and Ultrastructural Changes in Root Cells of Developing Rice Seedlings," Journal of Plant Physiology, Vol. 164, No. 11, 2007, pp. 1419-1428.

http://dx.doi.org/10.1016/j.jplph.2007.01.012 